\title{
Distribution of retinol in rat liver cells: effect of age, sex and nutritional status
}

\author{
BY RUNE BLOMHOFF, TROND BERG AND KAARE R. NORUM \\ Institute for Nutrition Research, School of Medicine, University of Oslo, \\ N-0316 Oslo 3, Norway
}

(Received 2 October 1987 - Accepted 21 March 1988)

\begin{abstract}
1. We have recently shown that the stellate cells, under normal conditions, contain a majority (more than $80 \%$ ) of the total store of retinol in liver (Blomhoff et al. 1985).

2. In the present work we have studied the role of the various liver cells in rats of different ages, sex and vitamin A status.

3. In most of these groups of rats, storage of retinol in parenchymal cells was proportional to the liver store of retinol, and less than $10 \%$ of total retinol in the liver could be recovered in the parenchymal cells. The only exception was parenchymal cells isolated from vitamin A-deficient rats. In rats containing $5 \mathrm{nmol}$ retinol/g liver, about $16 \%$ of total retinol could be recovered in parenchymal cells, while in rats with only $1 \mathrm{nmol}$ retinol $/ \mathrm{g}$ liver, about $40 \%$ of total retinol could be recovered in parenchymal cells.

4. These results indicate that parenchymal cells played a minor role in liver storage of retinol, and that stellate cells stored more than $90 \%$ of liver retinol in most instances. Only in rats with a low retinol status did the percentage of retinol in parenchymal cells increase.
\end{abstract}

In a previous report (Blomhoff et al. 1985) we have shown that hepatic perisinusoidal stellate cells (also called fat-storing cells) are the main storage site for retinol in the rat. Our findings suggested that under normal conditions as much as $80 \%$ or more of the total liver retinoids might be stored in stellate cells with the rest stored in parenchymal cells. Isolated parenchymal and stellate cells also contained enzymes and intracellular binding proteins involved in retinol metabolism. Isolated endothelial cells and Kupffer cells contained very low levels of these components (Blomhoff et al. 1985).

The method for isolating parenchymal liver cells most often involves collagenase perfusion of the liver and differential centrifugation of the total liver cell suspension (Seglen, 1976; Tolleshaug et al. 1977; Olson \& Gunning, 1983). However, by analysing the parenchymal-cell fraction in the fluorescent microscope, one becomes aware of the numerous stellate cells which contain lipid droplets with autofluorescent retinol. We found that parenchymal cells isolated by this method are contaminated with 5-10\% stellate cells (Blomhoff et al. 1985). Since stellate cells contain 100-200 times more retinol than parenchymal cells, it is difficult to quantify the exact amount of retinol in parenchymal cells using traditional methods.

In the present study we have used a refined method which includes centrifugal elutriation to purify the parenchymal liver cells. After centrifugal elutriation, the parenchymal-cell fraction contains less than $0.1 \%$ stellate cells. Based on this method we have determined the quantitative role of parenchymal cells in the hepatic storage of retinol in rats of different ages, sex and nutritional status.

\section{MATERIALS AND METHODS \\ Chemicals}

Percoll and Nycodenz were purchased from Pharmacia Fine Chemicals AB, Sweden and Nycomed A/S, Oslo, Norway respectively. Collagenase (type IV, EC 3.4.24.3) and pronase (type XXI) we obtained from Sigma Chemical Co., Poole, Dorset. 


\section{Animals}

Wistar rats of both sexes (initial age 4 weeks) were fed on an ordinary pelleted diet (no. 3155; AREX, Møllesentralen, Norway) which contained about $9.4 \mu \mathrm{mol}$ retinol $(50 \%$ as retinyl acetate and $50 \%$ as retinyl palmitate) $/ \mathrm{kg}$. A group of male rats (4 weeks old) was fed on a retinol-deficient diet (EWOS A/B, Södertälje, Sweden) for 8-10 weeks, at which time they stopped gaining weight. Another group of male rats (6 weeks old) were given $2.4 \mathrm{mg}$ retinol $/ \mathrm{kg}$ body-weight per $\mathrm{d}$ for a period of $45 \mathrm{~d}$.

\section{Preparation of parenchymal liver cells}

Total liver cell suspensions were prepared by a modified (Tolleshaug et al. 1977) collagenase perfusion technique (Seglen, 1976). Parenchymal cells were isolated from the total liver cell suspension by differential centrifugation (Tolleshaug et al. 1977), and by centrifugal elutriation. Cells were introduced into the elutriation chamber at a flow-rate of $18 \mathrm{ml} / \mathrm{min}$ and a rotor speed of $1200 \mathrm{rev} / \mathrm{min}$ (Blomhoff et al. $1984 \mathrm{~b}$ ). Pure parenchymal cells were washed out at a rotor speed of $45 \mathrm{ml} / \mathrm{min}$. About $98 \%$ of the isolated parenchymal cells were viable as determined by the trypan blue exclusion test. The parenchymal-cell suspension was contaminated with less than $0 \cdot 1 \%$ endothelial cells, Kupffer cells or stellate cells. Endothelial cells, Kupffer cells and stellate cells were identified as described below. About $40 \%$ of the parenchymal cells estimated to be present in intact liver (Munthe-Kaas et al. 1976) were recovered in the isolated parenchymal-cell suspension. Parenchymal cells were identified by light microscopy and by transmission electron microscopy (Plate $1(a)$ ).

\section{Preparation of non-parenchymal liver cells}

Non-parenchymal cells were prepared from total liver cell suspensions by differential centrifugation (Berg \& Boman, 1973), followed by centrifugation in $200 \mathrm{~g}$ Nycodenz/1 (Blomhoff et al. 1984c) to remove cell debris. The yield of cells by this method was about $32 \%$, and the non-parenchymal-cell suspension contained about $72 \%$ endothelial cells, $17 \%$ Kupffer cells and $8 \%$ stellate cells.

\section{Preparation and identification of endothelial liver cells}

Total liver-cell suspensions were treated with enterotoxin from Clostridium perfringens as described by Blomhoff et al. $(1984 \mathrm{c})$. The enterotoxin rendered the parenchymal cells leaky, and these cells were separated from the non-parenchymal cells by centrifugation in a HEPES-buffered minimal salt solution (Tolleshaug et al. 1977) containing $200 \mathrm{~g} \mathrm{Nycodenz/}$ 1. Endothelial cells were separated from the other non-parenchymal cells by centrifugal elutriation (Blomhoff et al. 1984c). Endothelial cells were identified following incubation with fluoresceinamine-conjugated ovalbumin, a compound which is selectively taken up by the endothelial cells (Smedsrød et al. 1982), and by transmission electron microscopy (Plate $1(b)$ ). None of the endothelial cells showed a positive cytochemical peroxidase reaction (Wisse, 1974). The endothelial-cell fractions were contaminated with $7 \%$ (mean of fifteen preparations) Kupffer cells and $2 \%$ (mean of seven preparations) stellate cells. About $55 \%$ of the endothelial cells estimated to be present in intact liver were recovered in the final endothelial-cell preparation.

\section{Preparation and identification of Kupffer cells}

Kupffer cells were purified by centrifugal elutriation (Blomhoff et al. 1984b) of nonparenchymal cells prepared from the total liver-cell suspension by incubation with pronase (Berg \& Boman, 1973). They were identified cytochemically by positive peroxidase reaction 
(Wisse, 1974), and by transmission electron microscopy (Plate 1(c)). The fraction containing the Kupffer cells was contaminated with $0.2 \%$ (mean of six preparations) parenchymal cells, $7 \%$ (mean of nine preparations) endothelial cells and 3\% (mean of nine preparations) stellate cells. The yield of Kupffer cells using this method was estimated to be about $45 \%$.

\section{Preparation and identification of stellate cells}

Non-parenchymal cells were prepared from the total liver-cell suspension by differential centrifugation (Nilsson \& Berg, 1977). The stellate cells were isolated further by Percoll density-gradient centrifugation (Blomhoff et al. 1984b). The fractions with densities between 1.025 and $1.035 \mathrm{~g} / \mathrm{ml}$ contained exclusively stellate cells. The stellate cells were identified both by transmission electron microscopy (Plate $1(d)$ ) and by fluorescence microscopy (Blomhoff et al. 1984b). Of the total number of stellate cells estimated to be present in liver, $8 \%$ were recovered in the final cell suspension.

\section{Quantification of total retinol}

For determination of total retinol (i.e. retinol plus retinyl esters) the fractions were saponified for $30 \mathrm{~min}$ at $57^{\circ}$ with $2 \mathrm{ml}$ potassium hydroxide $(100 \mathrm{~g} / \mathrm{l})$ in ethanol $(910 \mathrm{ml} /$ 1) in the presence of pyrogallol $(10 \mathrm{~g} / 1)$. Total retinol was then extracted into $5 \mathrm{ml}$ hexane and $2 \mathrm{ml}$ water. A $4 \mathrm{ml}$ portion of the hexane phase was transferred to new vials, and the internal standard (retinyl acetate) was added. The hexane was evaporated under nitrogen. The residue was dissolved in a small volume of methanol, and a portion was injected on to a high-performance liquid chromatographic (HPLC) column. The column used was a $5 \mu \mathrm{m}$ Supelcosil LC-8 column with a Waters model 440 detector monitoring absorbance at $313 \mathrm{~nm}$. Retinol was eluted in water: methanol $(7 \cdot 5: 92 \cdot 5, \mathrm{v} / \mathrm{v})$ at a flow rate $01.5 \mathrm{ml} / \mathrm{min}$. Quantification of total retinol was performed as described by Blomhoff et al. (1985).

\section{Analysis of free retinol and retinyl esters}

Whole liver and cell homogenates were extracted with ethanol and hexane. The homogenates $(0 \cdot 1-0.5 \mathrm{ml})$ were deproteinized with $96 \%$ ethanol, mixed thoroughly and, after a period of $30 \mathrm{~min}, 5 \mathrm{ml}$ hexane was added for extraction. The procedure was thereafter essentially as described for 'Quantification of total retinol' (above). The HPLC column (LC-8) was eluted with water: methanol $(7.5: 92.5, \mathrm{v} / \mathrm{v})$ at a flow rate of $1.5 \mathrm{ml} / \mathrm{min}$. Retinyl ester standards (Sigma Chemical Co.) were injected separately on to the same column to determine the position of the three main ester peaks, i.e. retinyl palmitate, retinyl oleate and retinyl stearate. A System L Computing Integrator from Spectra Physics, Santa Clara, CA, was used for calculating percentage distribution, assuming an equal chromatographic area per mol retinol and its esters.

\section{RESULTS}

Total retinol in liver cells isolated from 3-month-old male rats

Total retinol (retinol plus retinyl ester) contents in different liver-cell fractions of rats were determined by HPLC. The results are presented in Table 1 . These findings show that isolated parenchymal cells contained about $0 \cdot 2 \mathrm{nmol}$ total retinol $/ 10^{6}$ cells. Of the nonparenchymal cells, only stellate cells contained considerable amounts of retinol (about $34 \mathrm{nmol}$ total retinol $/ 10^{6}$ cells). Assuming that $1 \mathrm{~g}$ liver contains $125 \times 10^{6}$ parenchymal cells (Munthe-Kass et al. 1976) and $9 \times 10^{6}$ stellate cells (Blomhoff et al. 1984 b), it follows that less than $10 \%$ of the total retinol in liver is present in parenchymal cells, with more than $90 \%$ of the total retinol contained in stellate cells. 
Table 1. Total retinol in liver cells isolated from 3-month-old male rats

(Total retinol (retinol plus retinyl esters) was quantified in liver cells isolated from 3-month-old male rats fed on a control pelleted diet. Values represent means, with their standard errors, for the number of rats given. When converting values from a per $10^{6}$ cells to a per $\mathrm{g}$ liver basis, it was assumed that liver contains $190 \times 10^{6}$ cells $/ g$ wet weight, and parenchymal cells, endothelial cells, Kupffer cells and stellate cells constitute 56,19,10 and 6\% of the hepatic cells respectively (Munthe-Kass et al. 1976; Blomhoff et al. $1984 c)$

\begin{tabular}{|c|c|c|c|c|}
\hline & \multirow[b]{3}{*}{ No. of rats } & \multicolumn{3}{|c|}{ Total retinol } \\
\hline & & \multicolumn{2}{|c|}{$\mathrm{nmol} / 10^{6}$ cells } & \multirow[b]{2}{*}{$\mathrm{nmol} / \mathrm{g}$ liver } \\
\hline & & Mean & $\mathrm{SE}$ & \\
\hline Parenchymal cells & 5 & $0 \cdot 2$ & 0.04 & 25 \\
\hline Non-parenchymal cells & 4 & $4 \cdot 5$ & 0.45 & 293 \\
\hline Endothelial cells & 4 & $<0.1$ & - & $<4$ \\
\hline Kupffer cells & 4 & $<0.1$ & - & $<2$ \\
\hline Stellate cells & 5 & $34 \cdot 1$ & $7 \cdot 31$ & 307 \\
\hline
\end{tabular}

\section{Table 2. The effects of age, sex and diet on total retinol in rat liver and isolated} parenchymal cells

(Total retinol (retinol plus retinyl esters) was quantified in total liver and parenchymal liver cells isolated from different groups of rats. Rats in group 4 were given an ordinary pelleted diet until they were 6 weeks of age, and then given a diet supplemented with $2.4 \mathrm{mg}$ retinol $/ \mathrm{kg}$ body-weight per $\mathrm{d}$ for a period of 6 weeks. Rats in groups 6 and 7 were fed on the ordinary pelleted diet until they were 4 weeks of age, and then on a vitamin A-deficient diet for 8 weeks and 10 weeks respectively (for further details, see p. 234). Values represent means, with their standard errors, for the number of rats given. When estimating the percentage of total hepatic retinol in parenchymal cells, it was assumed that $1 \mathrm{~g}$ liver contains $125 \times 10^{6}$ cells)

\begin{tabular}{|c|c|c|c|c|c|c|c|c|c|c|}
\hline \multirow[b]{3}{*}{ Group } & \multirow[b]{3}{*}{ Sex } & \multirow{3}{*}{$\begin{array}{c}\text { Age } \\
\text { (months) }\end{array}$} & \multirow{3}{*}{$\begin{array}{l}\text { Retinol } \\
\text { in diet }\end{array}$} & \multirow{3}{*}{$\begin{array}{c}\text { No. } \\
\text { of } \\
\text { rats }\end{array}$} & \multicolumn{6}{|c|}{ Total retinol } \\
\hline & & & & & \multicolumn{2}{|c|}{$\begin{array}{c}\mathrm{nmol} / \mathrm{g} \\
\text { liver }\end{array}$} & \multicolumn{2}{|c|}{$\begin{array}{c}\mathrm{nmol} / 10^{6} \\
\text { parenchymal } \\
\text { cells }\end{array}$} & \multirow{2}{*}{$\begin{array}{c}\mathrm{nmol} / \\
125 \times 10^{6} \\
\text { parenchymal } \\
\text { cells }\end{array}$} & \multirow{2}{*}{$\begin{array}{c}\text { Percentage } \\
\text { estimated in } \\
\text { parenchyma } \\
\text { cells }\end{array}$} \\
\hline & & & & & Mean & $\mathbf{S E}$ & Mean & $\mathbf{S E}$ & & \\
\hline 1 & Male & 3 & Adequate & 10 & 539 & 20 & $0 \cdot 15$ & 0.026 & 19 & 4 \\
\hline 2 & Male & 7 & Adequate & 6 & 777 & 107 & 0.50 & 0.058 & 62 & 8 \\
\hline 3 & Male & 12 & Adequate & 9 & 1761 & 239 & 0.67 & 0.044 & 84 & 5 \\
\hline 4 & Male & 3 & Excess & 5 & 6710 & 109 & 3.41 & $0 \cdot 270$ & 427 & 6 \\
\hline 5 & Female & 3 & Adequate & 4 & 1730 & 432 & $0 \cdot 42$ & 0.073 & 53 & 3 \\
\hline 6 & Male & 3 & Deficient & 5 & 5 & 0.8 & 0.006 & $0 \cdot 001$ & 0.8 & 16 \\
\hline 7 & Male & 3.5 & Deficient & 3 & 1 & $0 \cdot 3$ & 0.003 & $0 \cdot 001$ & 0.4 & 40 \\
\hline
\end{tabular}

\section{Quantification of free retinol and retinyl esters in liver cells isolated from 3-month-old male rats}

The percentage of free retinol and retinyl esters in parenchymal and stellate cells was determined by HPLC. Of the total retinol detected in isolated parenchymal cells, $30.8 \%$ (mean of five preparations) was recovered as free retinol, while the rest was recovered as retinyl esters. In stellate cells, nearly all the total retinol was present as retinyl esters, and less than $1 \%$ was recovered as free retinol. 


\section{Total retinol in liver and parenchymal cells isolated from rats of different ages, sex and nutritional status}

In the next series of experiments we quantified the amount of total retinol in liver and parenchymal cells isolated from 3-, 7- and 12-month-old male rats, 3-month-old female rats, 3-month-old male rats fed on a retinol-deficient diet, and 3-month-old male rats fed on excess retinol (Table 2). The total retinol content of the liver increased considerably with age, from about $540 \mathrm{nmol} / \mathrm{g}$ liver in 3-month-old rats to about $1760 \mathrm{nmol} / \mathrm{g}$ liver in $12-$ month-old male rats. The 3-month-old female rats contained about three times more total retinol than their male counterparts. While male rats fed on a retinol-deficient diet for 8-10 weeks contained less than $10 \mathrm{nmol}$ total retinol/g liver, 3-month-old male rats given $2.4 \mathrm{mg}$ retinol $/ \mathrm{kg}$ body-weight per $\mathrm{d}$ for $45 \mathrm{~d}$ contained more than $6000 \mathrm{nmol}$ total retinol $/ \mathrm{g}$ liver.

In most of these groups of rats, the amount of total retinol found in parenchymal cells was approximately proportional to the total retinol content in the liver (Table 2). Less than $10 \%$ of total retinol in the liver was recovered in the parenchymal cells. The only exception was parenchymal cells isolated from retinol-deficient rats. In rats having $5 \mathrm{nmol} \mathrm{retinol} / \mathrm{g}$ liver, about $16 \%$ of the total retinol was estimated to be present in parenchymal cells, while in rats having only $1 \mathrm{nmol}$ retinol/g liver, about $40 \%$ was present in parenchymal cells.

\section{DISCUSSION}

Retinol absorbed in the intestine is esterified and transported via the lymphatic route in chylomicrons and their remnants (Goodman et al. 1965). The retinyl esters remain with the chylomicron remnant particles, and are removed from the circulation by the liver (Blomhoff et al. 1982, 1984a).

Studies have indicated that chylomicron-remnant retinyl esters are mainly taken up by parenchymal liver cells (Blomhoff et al. 1982). The newly endocytosed vitamin A is, however, transferred from the parenchymal cells to the perisinusoidal stellate cells in the liver shortly after uptake (Blomhoff et al. 1982, 1984 b). Furthermore, recent work in our laboratory (Blomhoff et al. 1985), and by others (Blaner et al. 1985), has shown that the stellate cells under normal conditions contain a majority (more than $80 \%$ ) of the total store of retinol in liver.

In agreement with previous reports (Batres \& Olson, 1987 b; Blaner et al. 1985; Blomhoff et al. 1985) our findings showed that most of the reserve (more than $90 \%$ ) of retinol was found in stellate cells in normal rats. The retinol in stellate cells was almost exclusively present as retinyl esters, and less than $1 \%$ was recovered as free retinol. In previous studies, it was, however, difficult to quantify the relative amounts of retinol and retinyl esters in parenchymal cells due to the contamination of stellate cells in the isolated parenchymal-cell fraction. Using a refined method to prepare parenchymal cells enabled us, in the present study, to quantify the amounts of retinol and retinyl esters in parenchymal cells. Of the total retinol detected in isolated parenchymal cells, about $30 \%$ was recovered as free retinol, while the rest was recovered as retinyl esters.

In rats given an excess of retinol, only $6 \%$ of the massive amount of total retinol (about $6.7 \mathrm{nmol} / \mathrm{g}$ liver) stored in liver was recovered in parenchymal cells. This is in agreement with a recent report from Batres \& Olson $(1987 a)$. In rats storing high amounts of retinol (about $1.4 \mathrm{nmol} / \mathrm{g}$ liver) they found that parenchymal cells isolated by centrifugal elutriation contained less than $5 \%$ of the total liver retinol.

In the present study we also investigated the role of the various liver cells in rats of 
different ages and sex, and in vitamin A-deficient rats. In most of these groups of rats, the amount of retinol found in parenchymal cells was roughly proportional to the total amount in the liver, and less than $10 \%$ of total retinol in the liver could be recovered in the parenchymal cells. This latter statement, however, did not apply to parenchymal cells isolated from retinol-deficient rats. In rats containing $5 \mathrm{nmol}$ retinol $/ \mathrm{g}$ liver, about $16 \%$ of the total liver retinol was present in parenchymal cells, while in rats with only $1 \mathrm{nmol}$ retinol/g liver, about $40 \%$ of the total retinol was present in parenchymal cells.

Batres \& Olson $(1987 b$ ) reported that parenchymal cells isolated from vitamin Adeficient Sprague-Dawley rats storing $5 \mathrm{nmol}$ retinol/g liver contained more than $80 \%$ total liver retinol. Although this value does not agree with ours, both studies suggest that the relative importance of parenchymal cells increases in vitamin A-deficient rats. The discrepancy between our values and those reported by Batres \& Olson $(1987 b)$ may be due to the difference in rat strain or feeding procedure.

Taken together, these results indicate that parenchymal cells play a minor role in liver storage of retinol, and that stellate cells store more than $90 \%$ of liver retinol, in most instances. Only in rats with a low retinol status does the percentage of retinol in parenchymal cells increase.

The authors thank Lizette B. Pedersen for expert technical assistance. This research was supported in part by grants from the Norwegian Cancer Society, the Norwegian Society for Fighting Cancer, Anders Jahres fond, Nordisk Insulinfond, Grethe Harbitz legat and Nansenfondet. They would also like to thank Ulla Kinde for most helpful assistance with electron microscopy.

\section{REFERENCES}

Batres, R. O. \& Olson, J. A. (1987a). Journal of Nutrition 117, 77-82.

Batres, R. O. \& Olson, J. A. (1987b). Journal of Nutrition 117, 874-879.

Berg, T. \& Boman, D. (1973). Biochimica et Biophysica Acta 321, 585-596.

Blaner, W., Hendriks, H., Brouwer, A., De Leeuw, A., Knook, D. \& Goodman, D. S. (1985). Journal of Lipid Research 26, 1241-1251.

Blomhoff, R., Helgerud, P., Dueland, S., Berg, T., Pedersen, J., Norum, K. R. \& Drevon, C. (1984 a). Biochimica et Biophysica Acta 722, 109-116.

Blomhoff, R., Helgerud, P., Rasmussen, M., Berg, T. \& Norum, K. (1982). Proceedings of the National Academy of Sciences, USA 79, 7326-7330.

Blomhoff, R., Holte, K., Næss, L. \& Berg, T. (1984b). Experimental Cell Research 150, 186-193.

Blomhoff, R., Rasmussen, M., Nilsson, A., Norum, K. R., Berg, T., Blaner, W. S., Kato, M., Mertz, J. R., Goodman, D. S., Eriksson, U. \& Peterson, P. A. (1985). Journal of Biological Chemistry 260, 13560-13565.

Blomhoff, R., Smedsrød, B., Eskild, W., Granum, P. \& Berg, T. (1984c). Experimental Cell Research 150, 194-204.

Goodman, D. S., Huang, H. S. \& Shiratori, T. (1965). Journal of Lipid Research 6, 390-396.

Knook, D. L., Blansjaar, N. \& Sleyster, E. C. (1977). Experimental Cell Research 109, 317-329.

Munthe-Kaas, A. C., Berg, T. \& Seljelid, R. (1976). Experimental Cell Research 99, 146-154.

Nilsson, M. \& Berg, T. (1977). Biochimica et Biophysica Acta 497, 171-182.

Olson, J. A. \& Gunning, D. (1983). Journal of Nutrition 113, 2184-2191.

Seglen, P. O. (1976). In Methods of Cell Biology, vol. 13, pp. 29-59 [D. M. Prescott, editor]. New York: Academic Press.

Smedsrød, B., Eriksson, S., Fraser, J. R. E., Laurent, T. C. \& Pertoft, H. (1982). In Sinusoidal Liver Cells, vol. 1, pp. 162-170 [D. L. Knook and E. Wisse, editors]. Amsterdam: Elsevier Biomedical Press.

Tolleshaug, T., Berg, T., Nilsson, M. \& Norum, K. R. (1977). Biochimica et Biophysica Acta 499, $73-84$.

Wisse, E. (1974). Journal of Ultrastructural Research 46, 393-426. 
British Journal of Nutrition, Vol. 60, No. 2

Plate $1(a)$

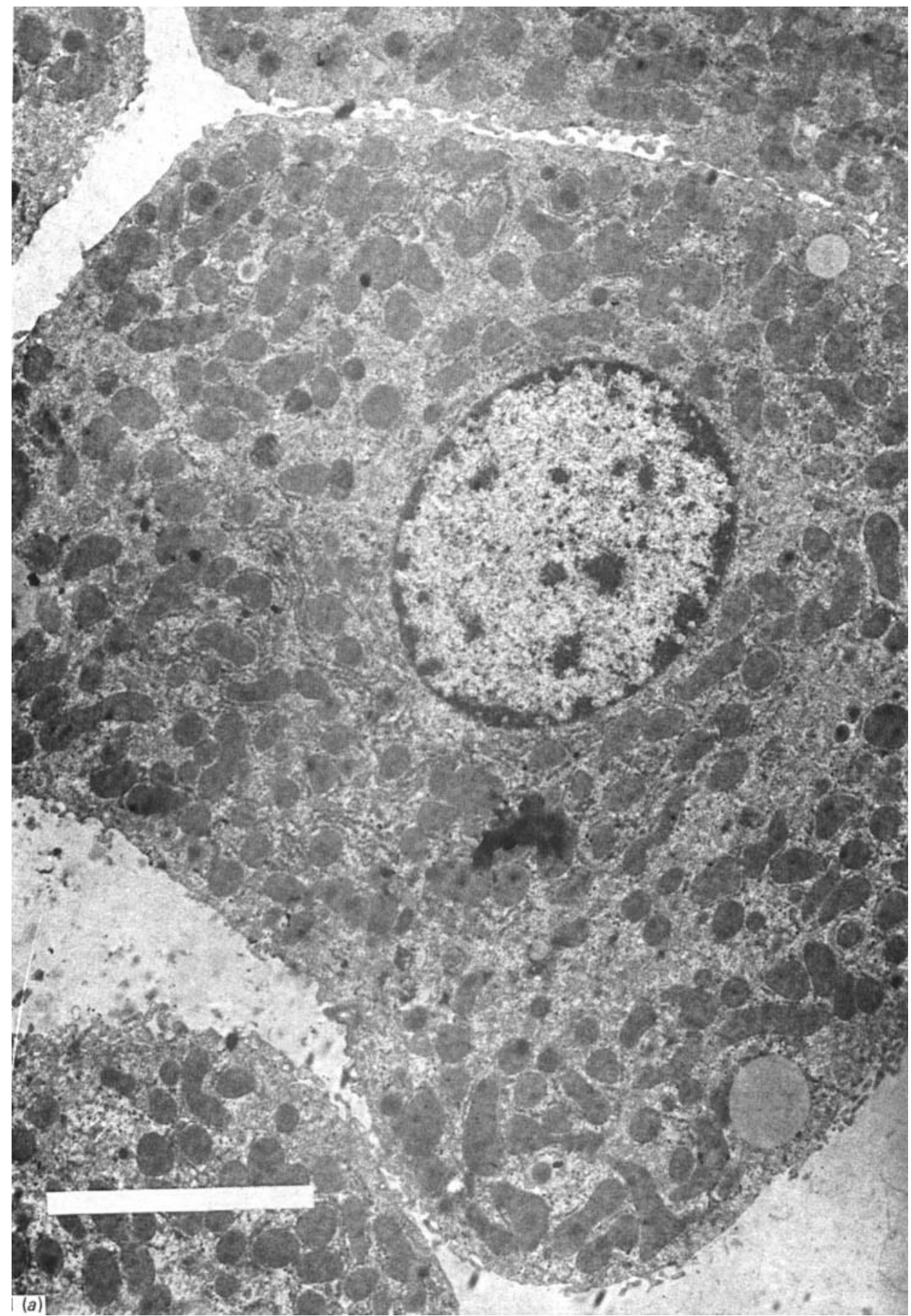

For description of Plate see page 239 
British Journal of Nutrition, Vol. 60, No. 2

Plate $1(b)$

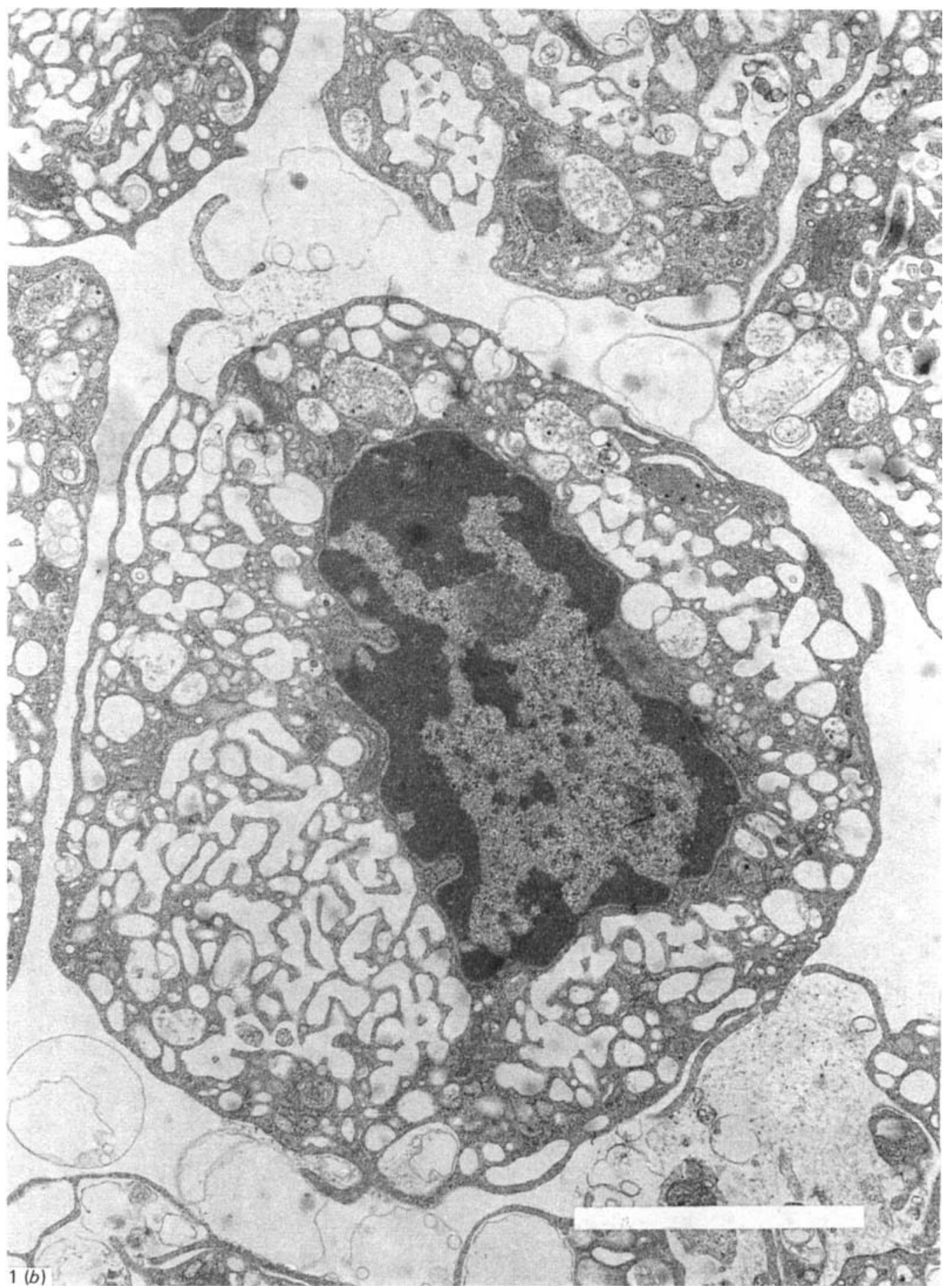


British Journal of Nutrition, Vol. 60, No. 2

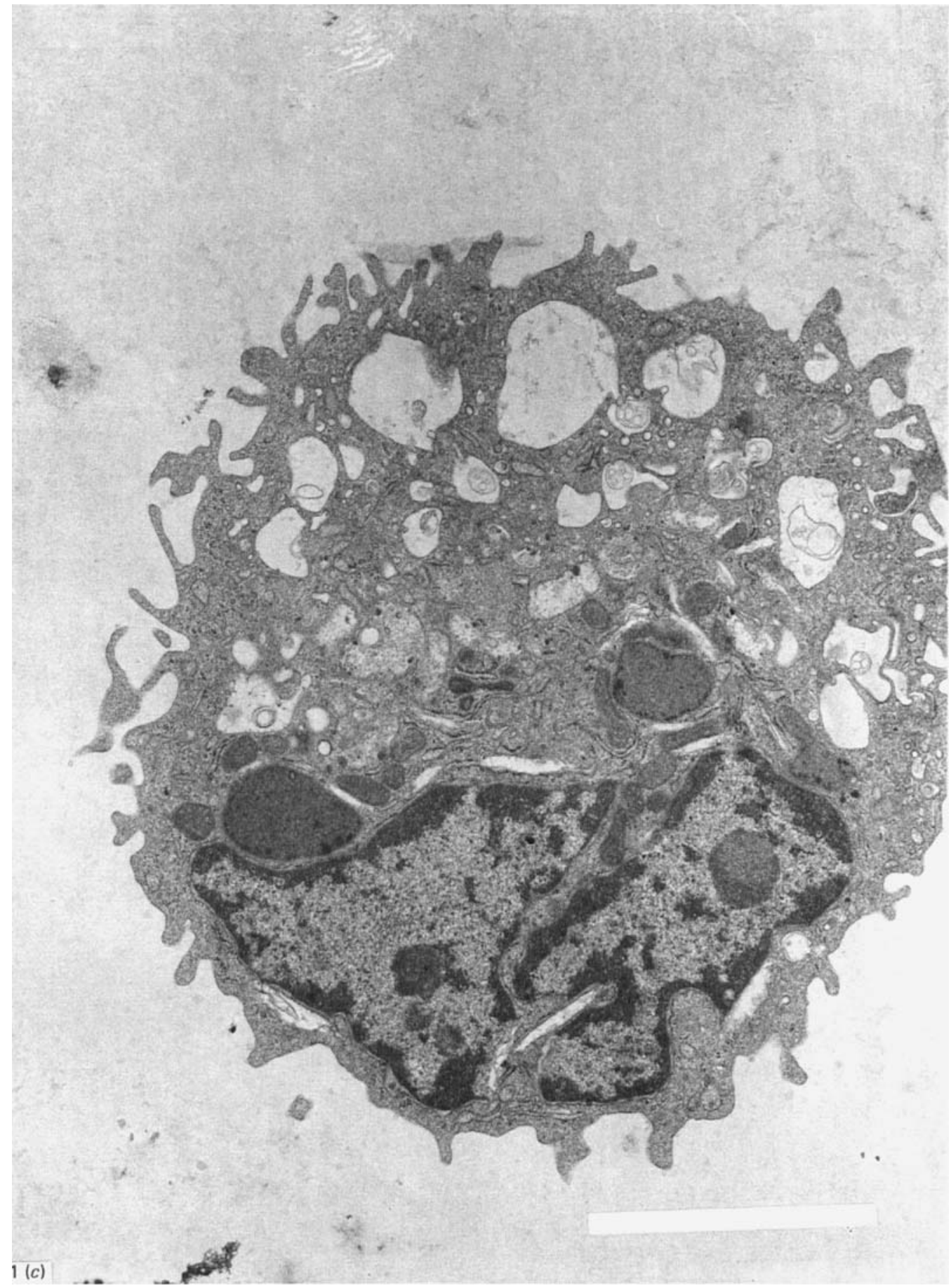


British Journal of Nutrition, Vol. 60, No. 2

Plate 1(d)

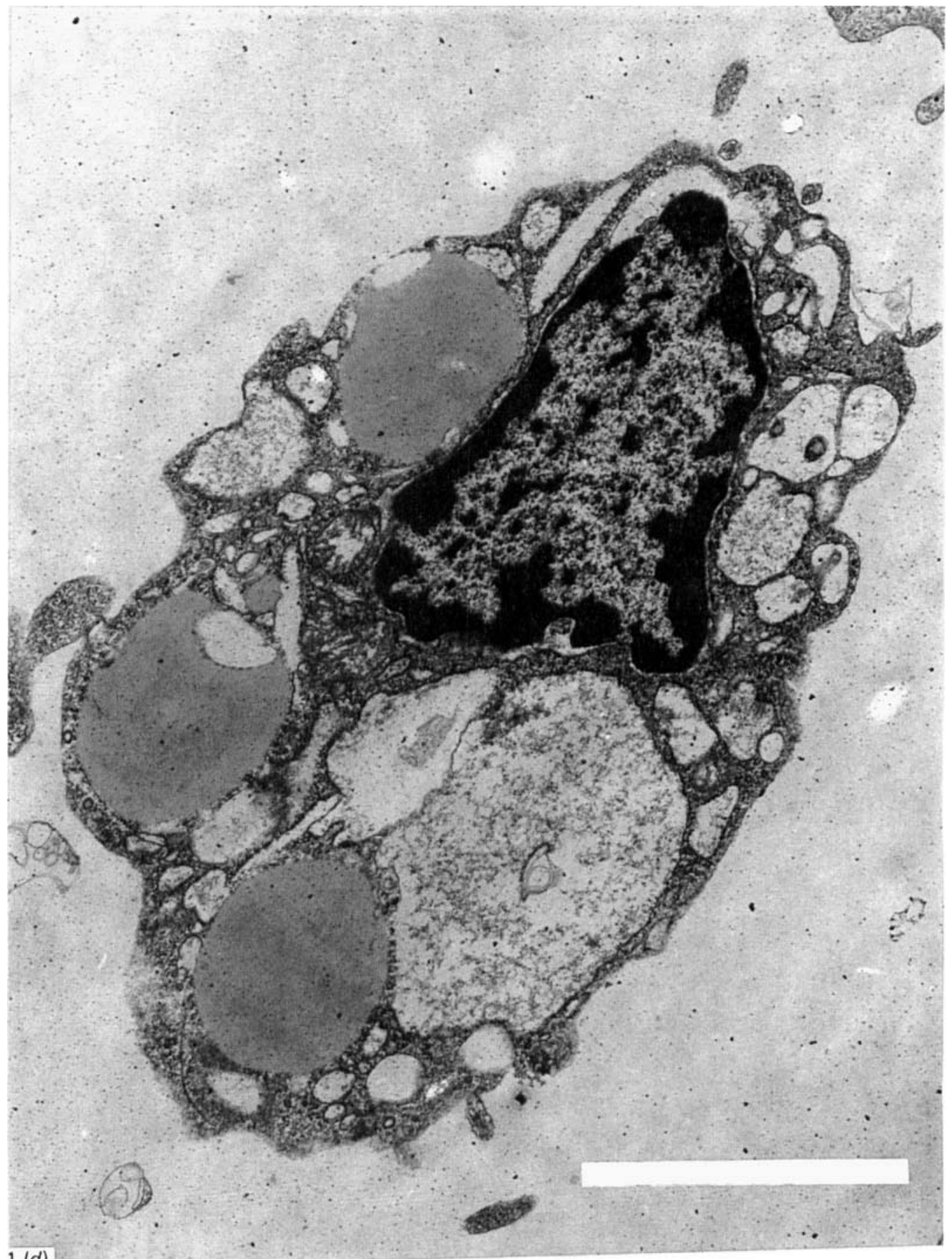




\section{EXPLANATION OF PLATE}

Plate 1. Transmission electron micrographs of freshly isolated rat liver parenchymal cells $(a)$, endothelial cells $(b)$, Kupffer cells $(c)$ and stellate cells $(d)$. Cell fractions were fixed with glutaraldehyde $(20 \mathrm{~g} / \mathrm{l})$ in $0 \cdot 17 \mathrm{M}$-cacodylate buffer, $\mathrm{pH} 7 \cdot 2$, for $2 \mathrm{~h}$ at $4^{\circ}$ and post-fixed in osmium tetroxide $(10 \mathrm{~g} / \mathrm{l})$ at $4^{\circ}$ overnight. Cells were then incubated with uranyl acetate $(5 \mathrm{~g} / \mathrm{l})$ for $1 \mathrm{~h}$ at room temperature and processed further for transmission electron microscopy. Bars $=5 \mu \mathrm{m}$. 